\title{
Preface
}

\section{Exploring seamount ecosystems and biodiversity in the tropical Western Pacific Ocean*}

\author{
Kuidong $\mathrm{XU}^{1,2,3, * *}$ \\ ${ }^{1}$ Laboratory of Marine Organism Taxonomy and Phylogeny, Shandong Province Key Laboratory of Experimental Marine \\ Biology, Institute of Oceanology, Center for Ocean Mega-Science, Chinese Academy of Sciences, Qingdao 266071, China \\ ${ }^{2}$ Laboratory for Marine Biology and Biotechnology, Pilot National Laboratory for Marine Science and Technology (Qingdao), \\ Qingdao 266237, China \\ ${ }^{3}$ University of Chinese Academy of Sciences, Beijing 100049, China
}

Received Jun. 6, 2021; accepted for publication Aug. 12, 2021

(C) Chinese Society for Oceanology and Limnology, Science Press and Springer-Verlag GmbH Germany, part of Springer Nature 2021

Seamounts are underwater mountains that rise at least $1000 \mathrm{~m}$ from the seafloor. They are generally extinct underwater volcanoes, of which a few remain active and support both vent and seamount communities. Seamounts constitute distinct submarine landscape of the world's ocean floor and over half the number of seamounts occur in the Pacific Ocean, among them the Magellan seamounts and Marcus-Wake seamounts are found to have the most developed cobalt-rich crusts. Seamounts have been known to support higher biomass and higher diversity of marine life than their surrounding deep-sea floors. The exploration of seabed minerals and the Environmental Impact Assessment (EIA) have continuously driven the seamount surveys.

Seamounts represent geographically separated islands, on which the biodiversity is vibrant. Geological and physicochemical factors combine to make seamounts fertile habitats for diverse deep-sea creatures. Because of their slow growth, high longevity, and high biodiversity, seamount cold-water corals and sponge aggregations are considered particularly vulnerable to anthropogenic activities such as bottom fishing and are thus classified as vulnerable marine ecosystems (VMEs). Seamounts and related deep-sea ecosystems are important and precious for life in deep oceans, and for sustainable human development.

Different seamounts have usually different habitat conditions, which result in different composition of deep-sea benthic community from that on the soft bottom seafloor around. Likewise, different types of substrates and depth gradients of seamounts provide diverse habitats for benthic organisms. However, the biodiversity of seamounts is not well documented, particularly in those underexplored areas, because biological samplings have been carried out in only about $1 \%$ of over 33000 seamounts distributed in the world's oceans. So far, explorations on Pacific seamount ecosystems and biodiversity have been conducted mainly in the middle-eastern and eastern Pacific and the southwestern Pacific. The tropical Indo-West Pacific region, as the world marine biodiversity center, is still one of the priority regions for future research of seamount ecosystems and biodiversity.

\section{Seamount expeditions in the tropical Western Pacific}

The Yap-Mariana Trench-Caroline Ridge and the Magellan Seamount Chain are both located in the tropical Western Pacific Ocean, where the seamount research is largely lacking (Clark et al., 2010). To bridge the knowledge gap, three seamount expeditions supported by the Strategic Priority Research Program of the Chinese Academy of Sciences were carried out in the sea areas of the Yap (Y3) Seamount, Mariana

\footnotetext{
* Supported by the Science \& Technology Basic Resources Investigation Program of China (No. 2017FY100800), the National Natural Science Foundation of China (No. 41930533), and the Strategic Priority Research Program of the Chinese Academy of Sciences (No. XDB42000000) ** Corresponding author: kxu@qdio.ac.cn
} 
(M2) Seamount, and Caroline (M4) Seamount during 2014-2017. Through the program, a platform for the exploration of seamount ecosystems has been well established, which promotes the discovery and research of seamount biodiversity.

Since 2017, a seamount project entitled "Scientific Investigation of Representative Seamount Ecosystems in the Western Pacific Ocean" supported by the Science \& Technology Basic Resources Investigation Program of China has been set up. This project aims to investigate the abiotic and biotic structure of seamount ecosystems and to establish a paradigm for interdisciplinary research on seamounts. Two seamount cruises were successfully implemented in the tropical Western Pacific. The first cruise was conducted in the Kocebu Guyot of the Magellan Seamount Chain in 2018, and the second was conducted in seamount (M5-M8) area of the Caroline Ridge in 2019.

All these expeditions were conducted with the R/V Kexue (Science in Chinese) equipped with the remotely operated vehicle (ROV) submersible Faxian (Discovery in Chinese), with which the megabenthic specimens were collected. The surveys cover a number of scientific areas in the domains of geology, hydrology, chemistry, ecology, and biodiversity. This special issue presents a part of the research progress of the seamount ecosystems and biodiversity in the tropical Western Pacific Ocean.

\section{Seamount geological and geochemical characteristics}

It has been estimated that there are over 33000 seamounts, with their habitats accounting for about $4.7 \%$ of the world's ocean floor (Yesson et al., 2011). However, the morphologies of seamounts are usually described in qualitative manners, yet few quantitative detections have been carried out. Taking a guyot on the Caroline Ridge as an example, Gan et al. (2021) quantified its multifractal features by applying multifractal detrended fluctuation analysis (MFDFA) based on the high-resolution multi-beam bathymetric data. The results indicate that the multifractal spectrum parameters of the seafloor have strong spatial dependency on the fluctuations of local landforms. This study helps better understand the character and surface processes on seamount.

Seamounts are the major place where submarine cobalt-rich crusts (or ferromanganese crusts) formed over millions of years. The Pacific Ocean has the oldest seamounts and is the most important cobalt crust region in the world. Cobalt-rich crusts have the potential to record paleo-oceanographic conditions during the mineralization process. Wang et al. (2021c) documented the geochemical characteristics of a crust sample from a seamount on the Caroline Ridge with cumulative growth time of $11.1 \pm 0.4 \mathrm{Myr}$. Analysis of metallic elements in the crust upper layer revealed an expansion event of oxygen minimum zone, and highreflectivity iron-rich laminae carried signals of surrounding volcanic activity. The data indicate that crust can be employed as an effective record of some major geological and paleo-oceanographic events that took place in the seamount area.

Seamounts are mostly composed of rocky substrates, which are mainly inhabited by suspending-feeding animals, such as cold-water corals and sponges. Coldwater corals are long-lived skeletal accreting marine animals, which might serve as another emerging archive of past ocean chemistry. Based on the analysis of a deep-sea gorgonian coral from the water depth of $1249 \mathrm{~m}$, Qu et al. (2021) documented the first data of the concentrations of the toxic trace metal $\mathrm{Hg}$ at different coral growth layers over the last seven centuries. The result suggests that anthropogenic pollution is not yet a clearly resolvable component in the deep oligotrophic Pacific waters. Such historical data provide valuable information helping to understand the oceanic cycle of $\mathrm{Hg}$ through time.

\section{Seamount physicochemical environments}

Seamounts are locations for a broad range of current-topography interactions and biophysical coupling and may support higher biomass than surrounding ocean waters, particularly in oligotrophic oceans (Clark et al., 2010). Shallow and deep seamounts may have different physicochemical and biological processes. Shi et al. (2021b) analyzed the physical properties around a shallow seamount namely M4 (summit depth less than $50 \mathrm{~m}$ ) and revealed the occurrence of an anticyclonic cap above the seamount. They showed that the interaction of the seamount and amplified tidal current resulted in an anticyclone circulation over the seamount, leading to a cold dome above the summit. The secondary circulation generates an upwelling at the outer border of the anticyclone eddy and an inward flow above it, forming a closed circulation system. Such a process may transport nutrients from deep-water layer to euphotic zone and stimulate phytoplankton biomass. Indeed, Ma et al. (2021) observed accumulations of nutrients and phytoplankton around the M4 Seamount, but such a "seamount effect" was not found in the deep seamount Kocebu Guyot (summit depth of 1195 m). 
Ocean warming and increased stratification are causing the decline of dissolved oxygen (DO) and the expansion of oxygen minimum zones (OMZs). Wang et al. (2021b) propose a parameter, $I_{\mathrm{OMZ}}$, to quantitatively describe the intensity of OMZs based on data obtained from three seamounts (namely Y3 Seamount, M2 Seamount, and Kocebu Guyot). According to the quantitative parameter, the intensity order of OMZs in the three seamounts areas is Kocebu $>$ M2 $>$ Y3. With higher $I_{\mathrm{OMZ}}$, the degradation of particulate organic carbon tends to be lower. This study provides a new way to quantitatively study the impact of OMZs on the efficiency of biological pump.

The climate variability induced by the El Niño Southern Oscillation (ENSO) cycle drives significant changes in the physical state of the tropical Western Pacific. A super El Niño event occurred in the equatorial Pacific in 2015. Based on analysis of suspended particulate matter (SPM) data and environmental data obtained in December 2014 and 2015, Gao et al. (2021) observed an enhanced upwelling in the Mindanao Dome region that carried cold but nutrient-rich water upward from the deep ocean to euphotic zone and induced a remarkable increase in phytoplankton blooms. The proportion of carbon storage in the tropical Western Pacific is estimated to be increased by more than $52 \%$ during the ENSO cycle, which greatly affected the regional and possibly even global carbon cycle.

\section{Seamount microbial diversity and ecology}

Dissolved oxygen (DO) plays an important role in shaping the vertical zonation of deep-sea benthos as well as plankton. The marine OMZs are globally expanding and intensifying under climate change. Sun et al. (2021) showed that in the Caroline seamount area in May 2019, the OMZ (with threshold of $3.5 \mathrm{mg} / \mathrm{L}$ ) existed in the depth range between $200 \mathrm{~m}$ to $2800 \mathrm{~m}$, with the $\mathrm{OMZ}$ core situated at 650 $1750 \mathrm{~m}$. Across stations, the bacterial richness and diversity showed unimodal pattern with decreasing DO with depths and peaked at the edge of OMZ. The OMZ harbored contrasting bacterial community composition from the other water layers. The findings help to clarify the potential responses of microbes and their involved biogeochemical processes to the expansion and intensification of OMZ.

Ciliates, with their broad range of body sizes, high diversity, and wide distribution, are the taxa that triggered the debate of microbial diversity and distribution. Previous study showed the alpha diversity of pelagic ciliates in the tropical Western Pacific peaked in the deep chlorophyll maximum (DCM) layer (Zhao et al., 2017), indicating that DCM depths might have a great impact on the vertical distribution of ciliate communities. Wang et al. (2021a) compared the planktonic ciliate trait structure over the Yap (Y3), Caroline (M4), and Mariana (M2) Seamounts and revealed that weak upwelling and DCM depths could influence the planktonic ciliate trait structure. The study represents a snapshot influence of the upwelling and the deeper DCM to ciliate trait structure.

The foraminifera sand sediment can be frequently seen at the top of guyots and in a place where the seamount is relatively flat in the tropical Western Pacific. However, the diversity and distribution of foraminifera on seamounts have rarely been studied. DNA high-throughput sequencing has been widely in estimating the diversity and distribution of marine microbes (Zhao et al., 2019; Huang et al., 2021). By using this method, Shi et al. (2021a) revealed that the Kocebu Guyot had a relatively high benthic foraminiferal diversity characterized by high proportions of monothalamiids and rotaliids. They detected a high proportion of rare OTUs and low identity OTUs, indicating a high genetic novelty of foraminiferal community. Comparative analysis indicates that seamounts could aggregate species of foraminiferans from a nearby deep-sea area. The data provide insight into the source-sink relationship of microbenthos on seamounts and adjoining deep-sea sediments.

\section{Seamount megabenthos taxonomy and phylogeny}

Cold-water corals and sponges are ecosystemengineering animals that constitute vulnerable marine ecosystems (VMEs). These habitat-forming species support diverse faunal assemblages that include commercially and ecologically important organisms. Sponges and corals are usually the most dominant groups on seamounts, where they spend the majority of their lives attached to the bottom. The mostrecorded seamount sponges are demosponges, in which Lithistid demosponges, also known as rock sponges, are a polyphyletic group of sponges. Gong et al. (2021) described a new species of Macandrewiidae, Macandrewia yapensis sp. nov., from a seamount named Y3 near the Yap Trench. This is the third species of Macandrewia found from the Pacific Ocean. Phylogenetic tree constructed with the partial COI sequences exhibits a more congruent relationship 
with morphological data of macandrewiid species compared to the $28 \mathrm{~S}$ gene tree.

Black corals (Antipatharia) are colonial hexacorallians with wiry black skeletons, and members of Schizopathidae are mainly distributed in deep seas. Lü et al. (2021) reported three species of Schizopathidae from two seamounts on the Caroline Ridge: Umbellapathes parva sp. nov., Telopathes cf. magna MacIsaac \& Best, 2013, and Stauropathes cf. punctata (Roule, 1905). The latter two species are the first records in the Western Pacific. The study presents that the corallum size and shape are specimendependent, while the size of polypar and abpolypar spines can serve as a main feature for differing species. The phylogenetic analyses using the ITS region and two mitochondrial fragments provide insight into their phylogenetic relationships among these species and related genera.

Octocorals are the most diverse corals in deep waters, encompassing the gorgonian corals, bamboo corals and sea pens, which frequently dominate the seamount megabenthic communities. Li et al. (2017) discovered a red-colored bubblegum coral (Paragorgiidae) namely Paragorgia rubra from a seamount (Y3) near the Yap Trench. Phylogenetic analyses indicate $P$. rubra and $P$. kaupeka form a clade and the two species diversified approximately $15 \mathrm{Ma}$. In this issue, Li et al. (2021a) described a new, white-colored bubblegum coral, Paragorgia papillata sp. nov., from a seamount on the Caroline Ridge. The genetic distance and phylogenetic analysis showed that $P$. papillata sp. nov. was closely related to P. coralloides. Paragorgia papillata sp. nov. is the third known white-colored species of the genus, and the fifth one found in the tropical Western Pacific.

Chrysogorgiids are a conspicuous group of octocorals on seamounts. Among the 14 genera within Chrysogorgiidae, Chrysogorgia is the most diverse genus consisting of 76 known species (Cairns, 2018; Xu et al., 2019, 2020a, b). Here, Xu et al. (2021) add two new species of Chrysogorgia collected from Caroline seamounts: Chrysogorgia pinniformis sp. nov. and $C$. varians sp. nov. The study indicates that the mtMutS marker has very limited usefulness for species delimitation and inner relationship inference of Chrysogorgia, while the 28S rDNA showed much higher level of genetic variation and could serve as a potential barcode for this genus. So far, 42 of 78 species of Chrysogorgia have been reported from the Indo-West Pacific, indicating this region might be a hotspot of Chrysogorgia species.
Pennatulacean corals, commonly known as sea pens, are a unique group of octocorals inhabit mainly soft-bottom environments. Based on specimens from two seamounts near the Yap Trench (Y3) and Mariana Trench (M2), Li et al. (2021b) proposed a new genus and a new species, Alloptilella splendida gen. et sp. nov., and resurrect Scytalium veneris (Thomson \& Henderson, 1906), a species formerly being considered as a junior synonym of Scytalium sarsii Herklots, 1858. The establishment of the new genus is supported by the morphological distinction, the genetic distances and the phylogenetic trees constructed by the concatenated mtMuts-COI-28S. The study indicates that both Pennatulidae and Virgulariidae are polyphyletic, calling for more morphological and molecular data.

Polychaetes are present inmost marine environments but are infrequently reported on seamounts. Polychaetes usually inhabit soft-bottom habitats, while seamounts mainly consist of rocky substrates, which are not preferable for most polychaetes (Surugiu et al., 2008). Wu et al. (2021) discovered a prominent polychaete characterized by remarkable harpoon notochaetae from seamounts on the Caroline Ridge, where it crawled slowly on rocky bottoms covered by fine sands. The new species Laetmonice iocasica sp. nov. is named after the Institute of Oceanology, Chinese Academy of Sciences (IOCAS) in celebration of the $70^{\text {th }}$ anniversary of IOCAS. It is closely related to L. producta Grube, 1877, but differs in both morphology and the genetic distance of the COI sequences. The study indicates that L. producta is probably distributed only at high latitudes of the Southern Hemisphere.

Nudibranch mollusks, commonly known as sea slugs, are colorful, shell-less gastropods distributed worldwide. Based on specimens collected from seamounts on the Caroline Ridge, Zhang and Zhang (2021) described a peculiar sea slug, Tritonia iocasica sp. nov., which is also named after the IOCAS. The establishment of the new species is well supported by both morphology and phylogenetic analyses. This species represents the first tritoniid nudibranch that is known to feed on octocorals of Melithaeidae. Based on their external features, T. iocasica sp. nov. can be clearly distinguished from all other known species of the genus.

Crustaceans are one of the most diverse animals on seamounts, where shrimps often constitute the most frequently found group, but the collection is often difficult due to their fast movement ability. An axiid 
shrimp specimen was obtained from a seamount on the Caroline Ridge by means of a swirling sucker installed on ROV in June 2019. Kou et al. (2021) described it as a new genus and species, Carolinaxius kexuae gen. et sp. nov., based on morphological and molecular data. The phylogenetic analysis indicates the new genus is closely related to Montanaxius, which occurs inside hexactinellid sponges on seamounts in the Indian Ocean.

The squat lobsters of Munidopsis are a highly diverse group widely distributed on seamounts, where they are usually associated with colonial corals. Dong et al. (2021) reported 11 new species of squat lobsters based on specimens collected from seamounts near the Yap Trench and Mariana Trench. Here, Dong and $\mathrm{Li}$ (2021) described two further new species, Munidopsis ahyongi sp. nov. and Munidopsis carolinensis sp. nov., from seamounts on the Caroline Ridge. Both the morphology and phylogenetic analysis based on the COI gene support the establishment of the new species.

The discovery of new genera and species provide better understanding of the seamount biodiversity and distribution in the tropical Western Pacific. The molecular data in conjunction with morphology help clarify many taxonomic confusions as well as their systematic positions. Nonetheless, these fascinating animals represent only a small part of the seamount diversity in the tropical Western Pacific Ocean, where seamounts are mostly densely distributed. Many more taxa of seamount megafauna are expected to be discovered with continuous expeditions and investigations.

Special thanks are due to our research team and the crews of ROV Faxian and R/V Kexue for successfully conducting the seamount surveys. I am very grateful to all anonymous reviewers for giving their critical comments and invaluable suggestions to improve the quality of the special issue. I hope this special issue would provide insight and inspiration to understand and protect the fascinating diversity and vulnerable ecosystems of the seamounts.

\section{References}

Cairns S D. 2018. Deep-water octocorals (Cnidaria, Anthozoa) from the Galápagos and Cocos Islands. Part 1: Suborder Calcaxonia. ZooKeys, 729: 1-46.

Clark M R, Rowden A A, Schlacher T, Williams A, Consalvey M, Stocks K I, Rogers A D, O'Hara T D, White M, Shank T M, Hall-Spencer J M. 2010. The ecology of seamounts: structure, function, and human impacts. Annual Review of Marine Science, 2: 253-278.
Dong D, Li X. 2021. Two new species of the genus Munidopsis Whiteaves, 1874 (Crustacea: Anomura: Munidopsidae) from the Caroline Ridge, South of Mariana Trench. Journal of Oceanology and Limnology, 39(5): 1841 1853 , https://doi.org/10.1007/s00343-021-0385-6.

Dong D, Gan Z, Li X. 2021. Descriptions of eleven new species of squat lobsters (Crustacea: Anomura) from seamounts around the Yap and Mariana Trenches with notes on DNA barcodes and phylogeny. Zoological Journal of the Linnean Society, 192(2): 306-355.

Gan Y, Ma X, Luan Z, Yan J. 2021. Morphology and multifractal features of a guyot in specific topographic vicinity in the Caroline Ridge, West Pacific. Journal of Oceanology and Limnology, 39(5): 1 591-1 604, https:// doi.org/10.1007/s00343-021-0383-8.

Gao W, Wang Z, Li X, Huang H. 2021. The increased storage of suspended particulate matter in the upper water of the tropical Western Pacific during the 2015/2016 super El Niño event. Journal of Oceanology and Limnology, 39(5): 1 675-1 689, https://doi.org/10.1007/s00343-021-0362-0.

Gong L, Lim S-C, Yang M, Li X. 2021. A new species of Macandrewia (Demospongiae, Tetractinellida, Macandrewiidae) from a seamount in the Western Pacific Ocean. Journal of Oceanology and Limnology, 39(5): 1 730-1 739, https://doi.org/10.1007/s00343-021-1042-9.

Huang P, Zhao F, Xu K. 2021. Complementary DNA sequencing (cDNA): an effective approach for assessing the diversity and distribution of marine benthic ciliates along hydrographic gradients. Journal of Oceanology and Limnology, 39(1): 208-222.

Kou Q, Poore G C B, Li X. 2021. A new genus and species of shrimp (Crustacea: Axiidea: Axiidae) from the Caroline Ridge, northwest Pacific. Journal of Oceanology and Limnology, 39(5): 1 830-1 840, https://doi.org/10.1007/ s00343-021-0446-x.

Li Y, Zhan Z, Xu K. 2017. Morphology and molecular phylogeny of Paragorgia rubra sp. nov. (Cnidaria: Octocorallia), a new bubblegum coral species from a seamount in the tropical Western Pacific. Chinese Journal of Oceanology and Limnology, 35(4): 803-814.

Li Y, Zhan Z, Xu K. 2021a. Paragorgia papillata sp. nov., a new bubblegum coral (Octocorallia: Paragorgiidae) from a seamount in the tropical Western Pacific. Journal of Oceanology and Limnology, 39(5): 1 758-1 766, https:// doi.org/10.1007/s00343-021-0404-7.

Li Y, Zhan Z, Xu K. 2021b. Establishment of Alloptilella splendida gen. et sp. nov. and resurrection of Scytalium sarsii Herklots, 1858, two sea pens (Cnidaria: Pennatulacea) from seamounts in the tropical Western Pacific. Journal of Oceanology and Limnology, 39(5): 1 790-1 804, https://doi.org/10.1007/s00343-021-1083-0.

Lü T, Zhan Z, Xu K. 2021. Morphology and molecular phylogeny of three black corals (Antipatharia, Schizopathidae) from seamounts in the Western Pacific Ocean, with description of a new species. Journal of Oceanology and Limnology, 39(5): 1 740-1 757, https:// doi.org/10.1007/s00343-021-0455-9. 
Ma J, Song J, Li X, Wang Q, Yuan H, Li N, Duan L. 2021. Analysis of differences in nutrients chemistry in seamount seawaters in the Kocebu and M5 seamounts in Western Pacific Ocean. Journal of Oceanology and Limnology, 39(5): 1 662-1 674, https://doi.org/10.1007/s00343-0200239-7.

Qu Y, Xu K, Li T, Wang M, Zhong H, Chen T. 2021. Deep-sea coral evidence for dissolved mercury evolution in the deep North Pacific Ocean over the last 700 years. Journal of Oceanology and Limnology, 39(5): 1 622-1 633, https:// doi.org/10.1007/s00343-021-0474-6.

Shi J, Lei Y, Li H, Li T. 2021a. NGS-metabarcoding revealing novel foraminiferal diversity in the Western Pacific Magellan seamount sediments. Journal of Oceanology and Limnology, 39(5): 1 718-1 729, https://doi. org/10.1007/s00343-021-0427-0.

Shi X, Wang Z, Huang H. 2021b. Physical oceanography of the Caroline M4 seamount in the tropical Western Pacific Ocean in summer 2017. Journal of Oceanology and Limnology, 39(5): 1 634-1 650, https://doi.org/10.1007/ s00343-021-0359-8.

Sun Q, Song J, Li X, Yuan H, Wang Q. 2021. The bacterial diversity and community composition altered in the oxygen minimum zone of the tropical Western Pacific Ocean. Journal of Oceanology and Limnology, 39(5): 1 690-1 704, https://doi.org/10.1007/s00343-021-0370-0.

Surugiu V, Dauvin J-C, Gillet P, Ruellet T. 2008. Can seamounts provide a good habitat for polychaete annelids? Example of the northeastern Atlantic seamounts. DeepSea Research I, 55: 1 515-1 531.

Wang C, Li H, Dong Y, Zhao L, Gregori G, Zhao Y, Zhang W, Xiao T. 2021a. Planktonic ciliate trait structure variation over Yap, Mariana and Caroline seamounts in the tropical Western Pacific Ocean. Journal of Oceanology and Limnology, 39(5): 1 705-1 717, https://doi.org/10.1007/ s00343-021-0476-4.

Wang Q, Song J, Li X, Ma J, Yuan H, Li N, Duan L. 2021 b. Characteristics and biogeochemical effects of oxygen minimum zones in typical seamount areas, Tropical Western Pacific. Journal of Oceanology and Limnology, 39(5): 1 651-1 661, https://doi.org/10.1007/s00343-0210349-x.

Wang Q, Wang Z, Liu K, Cui Q, Shi X. 2021c. Geochemical characteristics and geological significance of ferromanganese crust from CM6 Seamount of the Caroline Ridge in the Western Pacific. Journal of
Oceanology and Limnology, 39(5): 1 605-1 621, https:// doi.org/10.1007/s00343-021-1032-y.

Wu X, Hutchings P, Murray A, Xu K. 2021. Laetmonice iocasica sp. nov., a new polychaete species (Annelida: Aphroditidae) from seamounts in the tropical Western Pacific, with remarks on L. producta Grube, 1877. Journal of Oceanology and Limnology, 39(5): 1 805-1 816, https://doi.org/10.1007/s00343-021-0413-6.

Xu Y, Li Y, Zhan Z, Xu K. 2019. Morphology and phylogenetic analysis of two new deep-sea species of Chrysogorgia (Cnidaria, Octocorallia, Chrysogorgiidae) from Kocebu Guyot (Magellan seamounts) in the Pacific Ocean. ZooKeys, 881: 91-107.

Xu Y, Zhan Z, Xu K. 2020a. Morphology and molecular phylogeny of three new deep-sea species of Chrysogorgia (Cnidaria, Octocorallia) from seamounts in the tropical Western Pacific Ocean. PeerJ, 8: e8832.

Xu Y, Zhan Z, Xu K. 2020b. Morphology and phylogenetic analysis of five deep-sea golden gorgonians (Cnidaria: Octocorallia: Chrysogorgiidae) in the Western Pacific Ocean, with description of a new species. ZooKeys, 989: 1-37.

Xu Y, Zhan Z, Xu K. 2021. Morphology and phylogeny of Chrysogorgia pinniformis sp. nov. and C. varians sp. nov., two golden corals from the Caroline seamounts in the tropical Western Pacific Ocean. Journal of Oceanology and Limnology, 39(5): 1 767-1 789, https://doi.org/10. 1007/s00343-021-0386-5.

Yesson C, Clark M R, Taylor M L, Rogers A D. 2011. The global distribution of seamounts based on 30 arc seconds bathymetry data. Deep-Sea Research I, 58: 442-453.

Zhang S, Zhang S. 2021. Tritonia iocasica sp. nov., a new tritoniid species from a seamount in the tropical Western Pacific (Heterobranchia: Tritoniidae). Journal of Oceanology and Limnology, 39(5): 1 817-1 829, https:// doi.org/10.1007/s00343-021-0408-3.

Zhao F, Filker S, Xu K, Huang P, Zheng S. 2017. Patterns and drivers of vertical distribution of the ciliate community from the surface to the abyssopelagic zone in the Western Pacific Ocean. Frontiers in Microbiology, 8: 2559.

Zhao F, Filker S, Xu K, Li J, Zhou T, Huang P. 2019. Effects of intragenomic polymorphism in the SSU rDNA on estimating marine microeukaryotic diversity: a test for ciliates using single-cell high-throughput DNA sequencing. Limnology and Oceanography: Methods, 17: 533-543. 